\title{
Uuden vuosituhannen myrskypilvet
}

Riikka Niemelä

Lontoossa helmikuussa 1884 John Ruskin kuvasi "The Storm-Cloud of the Nineteenth Century" -luennolla havaintojaan sään muutoksista. Keskellä teollista vallankumousta elänyt Ruskin oli huolissaan ilmansaasteen vaikutuksista ympäristöön ja kehotti kuulijoita tarkkailemaan taivaan merkkejä; meteorologien sivuuttamia synkkiä sääilmiöitä, täysin uudenlaisia pilviä ja tuulia.

Helsingissä syyskuussa 2019 algoritmit sysäävät uutisvirtaani yhä uusia kuvia Amazonin liekehtivästä sademetsästä: koukeroisia savupylväitä punertavan, beessin ja harmaan sävyissä, karttoja ilmakehään nousevan hiilidioksidin määristä, ilmakuvia maastossa etenevän palon rajaamista muo- doista ja vaitonaisia maisemia, joissa karrelle palaneet puunrungot pistävät esiin planeettamme tulen mustaamista keuhkoista.

Samankaltainen huoli, joka käänsi Ruskinin katseen taivaalle, on saanut monet taiteen ja visuaalisen kulttuurin tutkijat analysoimaan ympäristön nykytilaan liittyviä ilmiöitä. October-lehden keväällä julkaisemassa "Climate Control" -esitelmässään Jonathan Crary pohti ilmastonmuutoksesta kertovien valokuvien, videoiden ja tilastojen mittavaa eksistenssiä mediassa. Hänen mukaansa ne luovat sekaannusta ja muodostavat lamauttavan koneiston, joka säilyttää nykyiset rakenteet ennallaan.

Vaikeiden ja shokeeraavien kuvien vaikutuksia on hahmoteltu jo pitkään. Susan Sontag huomautti On Photography -kirjassa (1977) kriisikuvan tunnelatauksen hiipuvan toistuessa. Jatkuva kuville altistuminen etäännyttää ja passivoi. Ekologisen katastrofin kuvastot voisi Jacques Rancièrea mukaillen ajatella myös "sietämättömiksi". Tuskaa aiheuttaessaan ne eivät yksiselitteisesti aktivoi toimintaan. Viime aikaisissa uutiskuvissa ilmastonmuutoksen traagisuus on kenties osin tästäkin syystä kätketty yhä useammin satumaisen kauniiden maisemien taa.

Ympäristökriisiin liittyvien tunteiden, kuten surun, epäuskon tai hämmennyksen käsitteleminen taiteen keinoin on olennaisempaa kuin kenties koskaan. Edeltävistä vuosikymmenistä poiketen horjuvat ekosysteemit ovatkin näkyvästi esillä myös vaikutusvaltaisissa näyttelyinstituutioissa. Tänä vuonna Venetsian biennaalin Kultaisen leijonan sai Liettuan paviljongin Sun \& Sea lämpenevän planeetan hiekkarannoilla kiireettöminä loikoilevine hahmoineen.

Ilmasto-oopperan kuvaaman lamaannuksen vastapari 2010-Iuvun ajankuvassa on hellittämätön protesti. Kiasmassa syyskuussa vierailleen taidehistorioitsija T. J. Demoksen luento "The Politics and Aesthetics of Climate Emergency" keskittyikin juuri aktivismin estetiikkaan luovine mielenilmaisuineen, 
iskulausekyltteineen ja savupommeissa vellovine mellakoineen. Peter Weibel luonnehti Global Activism -kirjassa (2015) massaprotesteja jopa uudenlaiseksi julkisen taiteen muodoksi.

Tällaiset medioissa kiertävät kuvat ovat myös lohdullisia; täynnä yhteisöllisyyttä, luovuutta, päättäväisyyttä ja järkähtämättömyyttä. Myös taide on jälleen kaduilla. Se rakentaa merkittävällä tavalla uudenlaista globaalia poliittista toimijuutta, jota Weibel luonnehti "performatiiviseksi demokratiaksi" ja Naomi Klein kuvasi jo 1990-luvun kirjoituksissaan. Huhtikuussa esimerkiksi Culture Declares Emergency -liikkeen lanseeranneen kulkueen etujoukot astelivat Waterloon sillalla taiteilijapari Ackroyd \& Harveyn ruohoa kasvavissa takeissa.

Taiteen ja kuvien tutkimus auttaa hahmottamaan ekologisessa kriisissä yhä vaikeaselkoisemmaksi muuttuvaa maailmaa. Posthumanismi on viitoittanut tapoja ajatella uudelleen inmisen luontosuhdetta ja asettanut tarkastelun kohteeksi myös ei-inhimillisen. Myös Tahitin luontoaiheinen teemanumero lähti liikkeelle kiinnostuksesta siihen, millä tavoin taidehistoria voi lisätä ymmärrystä luonnon havaitsemisen ja

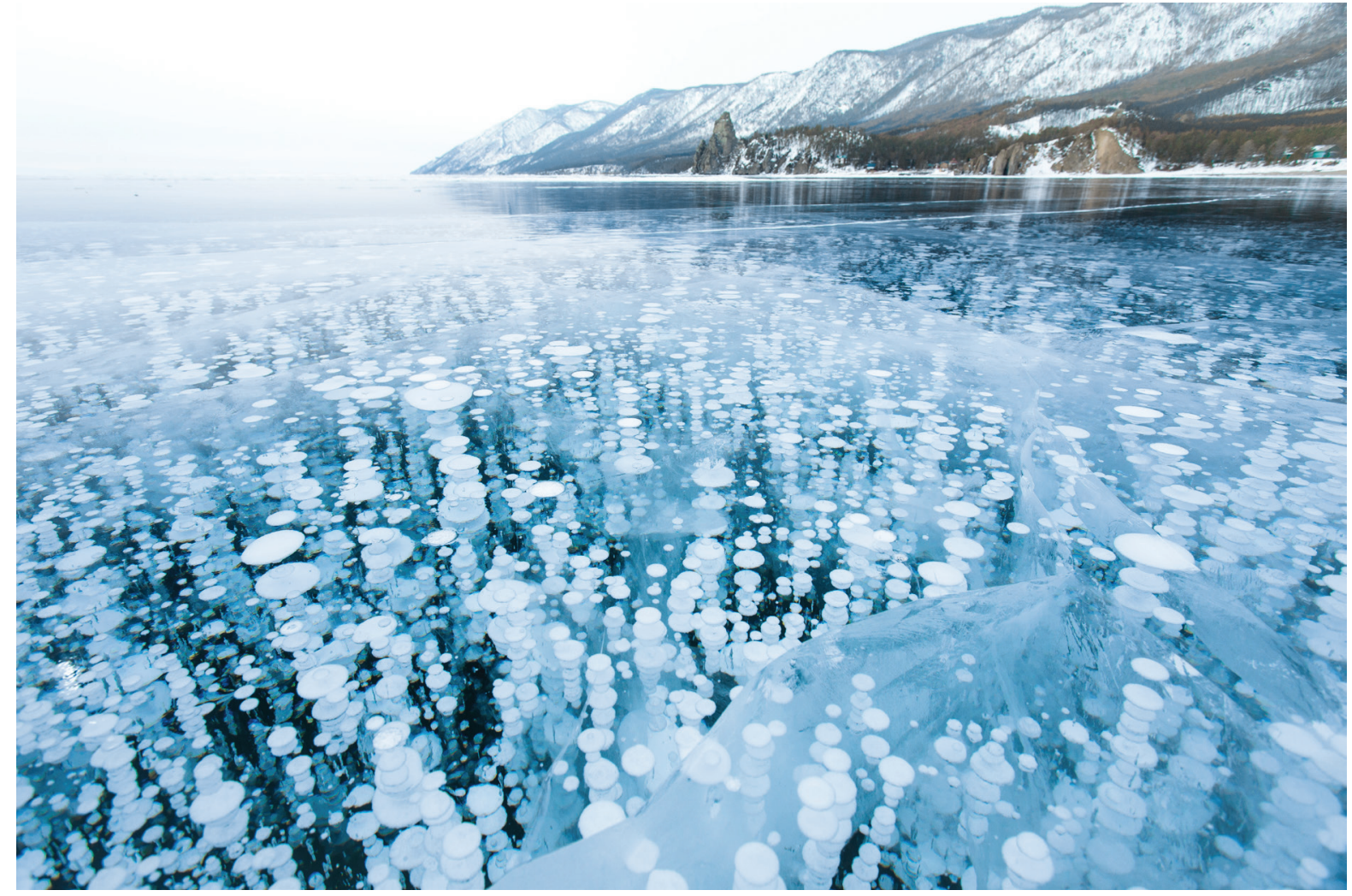

Metaanikuplia Baikaljärvessä. Kuva: iStock.com/Streluk

tulkitsemisen tavoista sekä ihmisen suhteesta ympäristöön. Numeron artikkeleissa tarkastellaan taiteen, kuvakulttuurin ja rakennettujen ympäristöjen heijastamia ja tuottamia luontosuhteita eri ajoilta. Millaiset käsitykset luonnonläheisyydestä ovat ohjanneet arkisten elinympäristöjen suunnittelua; mitä luontoon eläytyminen merkitsee valokuvaajalle tai kuvantutkijalle; millaisia edeltäjiä inhimillisen ja ei-inhimillisen toisiinsa kietovalla nykytaiteella on taiteen historiassa; tai miten taiteen ilmaisuvälineet auttavat katsomaan luontoa uusin tavoin? 